\title{
Characterisation of immune responses to food allergens in mice
}

\author{
Rebecca J. Dearman* and Ian Kimber \\ Syngenta Central Toxicology Laboratory, Alderley Park, Macclesfield, Cheshire SK10 4TJ, UK
}

\begin{abstract}
There is considerable interest in the development and evaluation of approaches for the safety assessment of novel foods, and in particular in methods for characterisation of allergenic potential. One strategy that has found favour is a tiered approach in which the potential of novel proteins to induce allergic sensitisation is assessed based on considerations of stability of the protein in a simulated gastric juice and homology with, or structural similarity to, known allergens. Linked to such an approach may be evaluation of serological identity with proteins known to cause allergic disease. With the aim of supplementing such approaches with a more direct measurement of potential allergenic activity, attempts have been made to characterise the quality of immune responses elicited in BALB/c strain mice. Such evaluations comprise measurement of IgG and IgE antibody production and (to a lesser extent) of induced cytokine expression patterns. Investigations to date suggest that in mice proteins provoke variable immune responses, those with the potential to cause allergic sensitisation stimulating $\operatorname{IgE}$ (and $\mathrm{IgG}$ ) antibody production. In contrast, non-allergenic, but nevertheless immunogenic, proteins are associated with IgG antibody responses in the absence of marked $\operatorname{IgE}$ production. Consistent with the selective activation of selective type $2 \mathrm{~T}$ lymphocyte responses, exposure of mice to allergenic protein is associated with preferential expression of IL-4, $-5,-10$ and -13 . Collectively these data suggest that characterisation of the nature of immune response induced in mice by proteins may provide a useful adjunct or alternative to current strategies for the assessment of allergenic potential.
\end{abstract}

Allergic sensitisation: Animal models: Food allergy: IgE antibody

Food allergy is an important health issue, the prevalence of which has been estimated recently to be $3 \cdot 5-4 \%$ of the adults in the USA and approximately $6-8 \%$ of the young children and infants (Fogg \& Spergel, 2003; Sampson, 2004). An increasing interest in the development of novel foods, and in particular in those derived from GM crops, has generated considerable debate about the likelihood of adverse health effects, with particular attention to allergenicity. The main issues are whether the product of a novel gene expressed in a crop plant will have the potential to induce de novo sensitisation or, by cross-reactivity with a known allergen, to elicit a hypersensitivity reaction in already-sensitised subjects. The requirements for safety assessments of the allergenicity of novel foods, and how these requirements might best be addressed, have been widely discussed (Taylor \& Hefle, 2001; Lack et al. 2002; Helm, 2003; Hollingworth et al. 2003). Most cases of food allergy in the USA and western Europe are associated with a relatively limited range of produce; the most commonly implicated sources being peanuts (Arachis hypogea), tree nuts (which include hazelnut (Corylus avellana), walnut (Juglans regia) and Brazil nut (Bertolletia excelsa)), pistachio nut (Pistacia vera) and macedemia nut and Queensland nut (Macedemia temifolia), hen's eggs, cow's milk, wheat, soyabeans, fish and shellfish (Sampson, 1988; Young et al. 1994; Bush \& Hefle, 1996; Hefle et al. 1996). Geographic and temporal changes in the pattern of specific food allergies emphasise the importance of the opportunities for exposure in the acquisition of sensitisation and demonstrate that the introduction of a novel food can be associated with an increased allergenic burden at the population level. Thus, the importance of different foods varies both geographically, as a function of regional dietary practices and preferences, and with time, as a result of the introduction of new food products (Hourihane, 1998). For instance, an increased

\footnotetext{
Abbreviation: Th, T-helper.

*Corresponding author: Dr Rebecca J. Dearman, fax + 441625 590996, email rebecca.dearman@syngenta.com
} 
frequency in allergy to sesame (Sesamum indicum L.) has been associated with more widespread use of the seed and its oil in food preparation (Kanny et al. 1996), and a similar increase in allergy to kiwi fruit (Actinidia chinensis Planch.) coincident with its introduction to and increased use in the UK has been observed (Lucas et al. 2004).

\section{Tiered approach for allergenicity safety assessment}

The International Life Sciences Institute Allergy and Immunology Institute in association with the International Food Biotechnology Council have suggested the first conceptual framework for the conduct of safety assessments for allergenicity (Metcalfe et al. 1996). A decision tree has been recommended in which the route taken for assessment of potential allergenicity is determined by whether or not the gene product of interest is derived from a source associated with human allergic disease. The following evaluations have been proposed: (a) consideration of the amino acid sequence homology with, or structural similarity to, allergenic proteins; (b) measurement of the resistance of novel proteins to digestion in a simulated gastric fluid; (c) assessment of the serological identity of the protein of interest with proven human allergens (Astwood et al. 1996; Metcalfe et al. 1996). Although this decision tree provides a useful approach to the identification of proteins that are likely to have sensitising activity based on their molecular or structural similarities with known allergens, the absence of serological or structural homology with already characterised protein allergens does not preclude inherent sensitising potential of a novel protein. Furthermore, although protein allergens are, in general, relatively resistant to digestion by pepsin in simulated gastric fluid (Astwood et al. 1996), this relationship is not absolute, as there have been reports of pepsin-resistant non-allergens (Thomas et al. 2004) and pepsin-sensitive allergens (Fu et al. 2002).

In addition to the approaches described earlier, there is therefore a need for methods for the identification of novel proteins with inherent sensitising potential that may lack structural homology or serological cross-reactivity with known allergens (Selgrade et al. 2003). This need was recognised by the consultation panel convened in 2001 by the FAO and WHO, and one conclusion reached by the panel was that animal models may contribute valuable information about the likely allergenicity of foods derived from GM crops (Food and Agriculture Organization/World Health Organization, 2001). This view has given considerable impetus to efforts directed towards the development of suitable animal models, including methods based on the use of mice (Dearman et al. 2001, 2003a,b; van Wijk et al. 2004), rats (Atkinson \& Miller, 1994; Atkinson et al. 1996; Knippels et al. 1998, 2000; Knippels \& Penninks, 2003), dogs (Ermel et al. 1997; Teuber et al. 2002) and swine (Helm et al. 2002). Although none of these approaches has yet been evaluated thoroughly, the application of an accurate and robust animal model, in concert with the other approaches summarised earlier, would be of great utility in safety assessment.

\section{Immunobiology of protein allergenicity}

Before describing the progress that has been made with a method using BALB/c strain mice, the underlying immunobiology of protein allergy will be considered. By definition, 'allergy' describes the adverse health effects that may result from the induction of a specific immune response. Although other (cell-mediated) immune reactions may play a central role in some circumstances (e.g. coeliac disease associated with gluten sensitivity), it is $\operatorname{IgE}$ antibody that is most commonly implicated in food allergy. Specific IgE antibody production is induced when a susceptible subject encounters the protein allergen in sufficient quantity and under appropriate conditions of exposure. The antibody distributes systemically and associates with tissue mast cells. If the now sensitised subject is exposed subsequently to the inducing allergen then a reaction will be provoked. The antigen will associate with, and cross-link, IgE antibody bound to mast cells, causing cellular degranulation and the release of both newlysynthesised and pre-formed inflammatory mediators (including histamine, serotonin, prostaglandins and leukotrienes) that act in concert to initiate a reaction locally (at the site of exposure) or systemically (as in anaphylaxis).

The initiation and maintenance of IgE antibody production depend on the development of a selective type 2 immune response. It has been recognised for some time that the qualitative characteristics of adaptive immune responses are governed largely by functional heterogeneity among T lymphocytes. Such functional diversity was first characterised in $\mathrm{CD}^{+}$T-helper (Th) cell populations (Mosmann et al. 1986; Mosmann \& Coffman, 1989). Although the situation is complex, the most differentiated subsets of Th cells, designated Th1 and Th2, develop during the evolution of immune responses and display phenotypes of selective cytokine secretion. Th2 cells produce cytokines (such as IL-4, -5, -10 and -13) that are required for the development of $\mathrm{IgE}$ antibody responses and that facilitate the elicitation of IgE-mediated allergic reactions (Finkelman et al. 1988b; Kimber \& Dearman, 1997). In contrast, products of Th1 cells (and, importantly, interferon- $\gamma$ ) antagonise IgE production and allergic hypersensitivity (Finkelman et al. 1988a; Kimber \& Dearman, 1997). The second major population of $\mathrm{T}$ lymphocytes (T-cytotoxic cells) also has functional subsets that contribute via cytokine production to the regulation of $\operatorname{IgE}$ responses (Mosmann \& Sad, 1996; Mosmann et al. 1997).

The effective acquisition of allergic sensitisation to food proteins will therefore require conditions that favour the selective generation of Th2-type immune responses. The assumption is that proteins differ in their ability to provoke a Th2-type response and thus their inherent allergenic potential. It could be argued, of course, that in theory all proteins are potential allergens if the levels of exposure have been high enough and the conditions of exposure appropriate. In practice, however, this argument does not appear to be valid, since only a small proportion of the food proteins to which individuals are regularly exposed in their diet is associated with allergic disease (Sampson, 1988; Young et al. 1994; Bush \& Hefle, 1996; Hefle et al. 1996). Furthermore, some protein allergens, such as 
those associated with allergy to peanuts, often cause persistent and severe sensitisation reactions, whereas others (including, for instance, some milk proteins) are characterised by less profound and more transient sensitisation (Pumphrey, 2000; Spergel et al. 2000; Bock et al. 2001).

These observations suggest that there is indeed a spectrum of allergenicity among proteins. An important question is what distinguishes protein allergens from other proteins that, despite being potentially immunogenic, fail to cause the acquisition of sensitisation. Among the features that may be important are: size; resistance to proteolytic digestion; glycosylation status; biological function (enzymic activity, storage protein etc.); overall immunogenicity; the ways in which the protein is recognised, internalised and processed for presentation to the immune system (Bufe, 1998; Aalberse, 2000; Huby et al. 2000; Bredehorst \& David, 2001). Despite the lack of a detailed understanding of the properties that determine whether a protein has the potential to be allergenic, attempts to identify inherent allergenic hazard are predicated on modelling such differences experimentally. Thus, animal models proposed for this purpose have focused on the measurement of induced IgE antibody responses or markers of Th2 cell activation.

\section{Assessment of allergenicity in mice: measurement of antibody responses}

In the authors' laboratory the BALB/c strain mouse has been utilised to evaluate the sensitising potential of protein allergens. The mouse offers some important advantages as an experimental model, including a sophisticated appreciation of the immune response and the availability of a range of reagents. The $\mathrm{BALB} / \mathrm{c}$ strain mouse is frequently selected for such studies because it is a high $\operatorname{IgE}$ responder, equivalent to an atopic phenotype. In order to examine the intrinsic potential of proteins to induce allergic responses, mice are treated with test proteins by systemic (intraperitoneal) exposure in the absence of adjuvant. Mice receive two intraperitoneal injections of the test protein $7 \mathrm{~d}$ apart and serum is prepared after a further $7 \mathrm{~d}$. Serum samples are analysed for specific IgE antibody responses by homologous passive cutaneous anaphylaxis assay and specific IgG antibodies are measured by ELISA. The strategy is to identify as potential allergens those proteins that have the ability to induce $\operatorname{IgE}$ antibody responses. These proteins can be distinguished from non-allergenic proteins that despite being antigenic, and therefore able to provoke IgG antibody production, either fail to elicit IgE or stimulate only low-titre IgE antibody. Experience with this approach and detailed methods have been described previously (Dearman \& Kimber, 2001; Dearman et al. 2001, 2003a,b; Atherton et al. 2002).

In the series of representative experiments illustrated in Fig. 1 mice ( $n$ 5) were exposed to peanut agglutinin (a minor peanut allergen; Burks et al. 1994; 0.1\%,w/v), to ovalbumin (a major allergen in chicken egg white; Hefle et al. 1996; $2 \%, \mathrm{w} / \mathrm{v}$ ) and a purified potato protein, potato agglutinin (a material considered to lack allergenicity; Jeannet-Peter et al. 1999; 5\%, w/v). Two independent

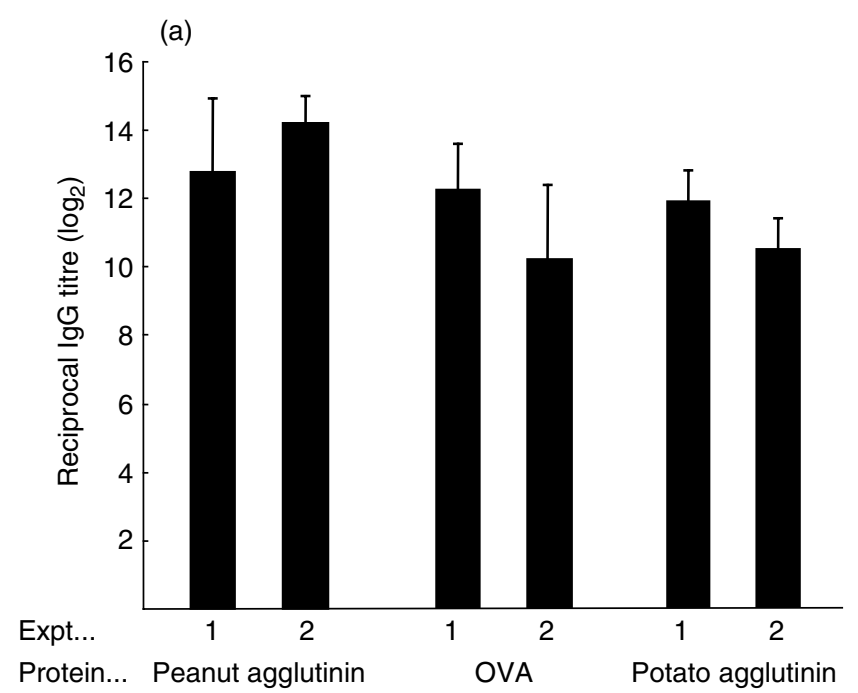

(b)

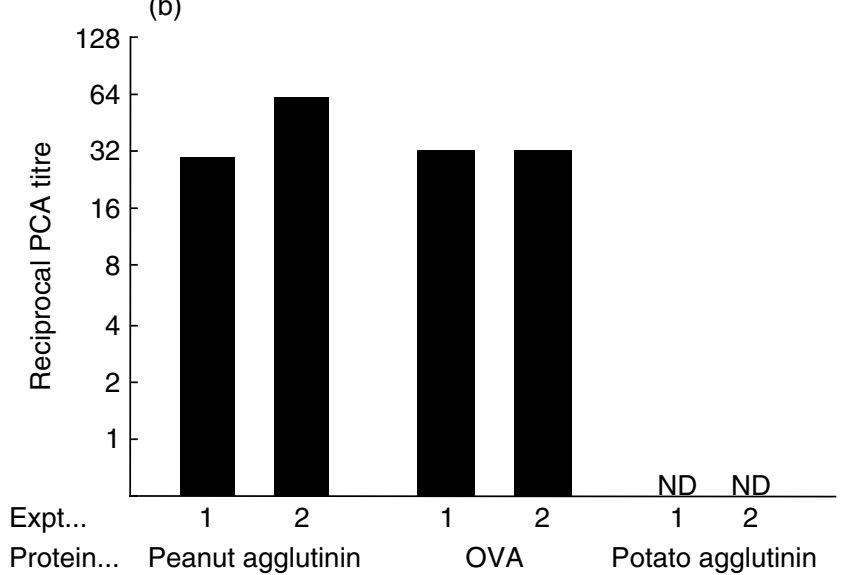

Fig. 1. Characterisation of antibody responses to selected proteins. Groups of BALB/c strain mice $(n 5)$ received $0.25 \mathrm{ml}$ peanut (Arachis hypogea) agglutinin $(0.1 \%, w / v)$, ovalbumin $(0.1 \%, w / v$; OVA) or potato agglutinin $(5 \%, \mathrm{w} / \mathrm{v})$ in PBS on days 0 and 7 . At $14 \mathrm{~d}$ after the initiation of exposure animals were exsanguinated and serum samples prepared. (a) Individual serum samples were analysed for the presence of protein-specific IgG antibody by ELISA. IgG titre is recorded as the highest dilution at which substrate conversion (optical density at $450 \mathrm{~nm}$ ) is $>0.5$. For control sera derived from naïve (untreated) mice readings never exceeded this value even at the highest serum concentration (1 in 25) tested. Data for reciprocal IgG titre $\left(\log _{2}\right)$ are expressed as means with their standard errors represented by vertical bars for each treatment group for two independent experiments (1 and 2). (b) Serum samples were pooled on an experimental group basis; serial doubling dilutions were prepared and used to derive $\operatorname{lgE}$ antibody titres by homologous passive cutaneous anaphylaxis (PCA) assay. In every analysis pooled sera from naïve (untreated) mice were tested concurrently and were uniformly negative. IgE antibody titre is expressed as the highest dilution of serum resulting in a positive PCA reaction in most recipient animals; results from two independent experiments (1 and 2) are shown (for detailed experimental protocols, see Dearman et al. 2003a). ND, not detectable with neat sera (titre of $<1$ ).

studies were performed, and it was found that each of the proteins is immunogenic in mice, inducing substantial $\mathrm{IgG}$ antibody responses. Although $\mathrm{IgG}$ responses to peanut agglutinin are somewhat more vigorous than those 
provoked by the other proteins, importantly that $\operatorname{IgG}$ titres induced by exposure to potato agglutinin are equivalent to those elicited by treatment with ovalbumin. However, there are marked differences in the capacity of these proteins to induce IgE responses, with relatively high-titre IgE antibody being provoked by both allergens while the potato protein fails to stimulate detectable $\operatorname{IgE}$ antibody. Importantly, these differences in $\operatorname{IgE}$ antibody production have been observed against a background of equivalent overall immunogenicity ( $\operatorname{IgG}$ antibody responses), at least in relation to ovalbumin and potato agglutinin. It is particularly interesting that potato agglutinin, which is believed to lack marked sensitising potential in man (unlike peanut agglutinin), does not induce marked IgE production. This finding demonstrates that not all agglutinins (or plant lectins) will stimulate IgE. In addition, this protein has been demonstrated to be very stable to digestion in simulated gastric fluid (Atherton et al. 2002), a suggested variable for the characterisation of allergenic potential (Astwood et al. 1996; Metcalfe et al. 1996). The theoretical basis for resistance to proteolytic digestion and an association with allergenicity is that allergens are stable proteins that therefore persist in the gastrointestinal tract in an intact form, allowing sufficient opportunity to interact with the immune system and to stimulate immune and allergic responses. This relationship between resistance to digestibility and allergenic activity is clearly not absolute, with some stable proteins failing to stimulate IgE antibody responses despite inducing robust IgG antibody responses.

Although further investigations with a wider range of proteins are required, the current view based on these and other studies is that this approach allows discrimination among proteins in terms of their ability to provoke $\operatorname{IgE}$ antibody, and on this basis it is possible to identify those proteins that have an inherent potential to cause allergic sensitisation.

\section{Assessment of allergenicity in mice: measurement of cytokine responses}

As described earlier, it has been hypothesised that proteins that are known to induce $\operatorname{IgE}$ antibody responses, and to cause allergic sensitisation, will induce in BALB/c strain mice the development of selective immune responses characterised by the preferential production of type 2 cytokines. Despite the low frequency of circulating allergenspecific cells in human subjects (using flow cytometric techniques to select for these rare cells) it has, for example, been demonstrated in human subjects (Turcanu et al. 2003) that peanut-allergic donors display a Th2 phenotype of cytokine expression, while in peanut-tolerant subjects, or in individuals who have outgrown their peanut allergy, there is a skewing towards a Th1 profile. There have been previous reports that protein or parasite allergens that provoke $\operatorname{IgE}$ antibody responses stimulate polarised Th2-type cytokine secretion profiles in various animal models (Bae et al. 1999; Li et al. 1999, 2000; Morafo et al. 2003; van Wijk et al. 2004). However, such studies have almost invariably required the co-administration of adjuvants, such as alum, that promote the development of Th2-type cells during sensitisation.

In other studies (Betts et al. 2004) the intrinsic ability of a protein allergen (peanut agglutinin) to provoke type 2 cytokine responses in the absence of adjuvant has been characterised at the levels of both mRNA expression and protein secretion. Cytokine profiles induced by specific stimulation of peanut-primed lymph node cells were compared with those elicited by culture with the T-cell mitogen concanavalin A. The results of these preliminary experiments suggest that, based on cytokine secretion and mRNA profiles, exposure of BALB/c strain mice to peanut agglutinin (a known peanut allergen) is associated with a selective type 2 response. When draining lymph node cells from peanut-agglutinin-sensitised mice are cultured in vitro with the same protein there are, compared with cells cultured in the presence of an irrelevant protein or with concanavalin A, relatively high levels of secreted IL-4, -5 , -10 and -13 , but lower levels of interferon- $\gamma$ and IL-12 (the latter being another cytokine associated with type 1 responses; Fig. 2). A similar profile is observed when cytokine mRNA expression is analysed by the ribonuclease protection assay, with mitogen stimulating higher levels of the type 1 cytokines interferon- $\gamma$ and IL-2, whereas peanut agglutinin stimulates more vigorous expression of transcripts for the type 2 cytokines IL-4, $-5,-10$ and -13 . There is a requirement for the lymph node cells to have been primed in vivo with allergen; lymph node cells derived from naïve (untreated) mice fail to up regulate cytokine protein or mRNA expression on culture with peanut agglutinin.

Although confirmation of the selectivity and sensitivity of the response is required using other allergens and nonallergens, these preliminary data suggest that it may prove possible in the future to use cytokine expression profiling as an adjunct or alternative to serological analyses for the characterisation of immune responses to protein allergens.

\section{General considerations: route of exposure, adjuvant and hazard $v$. risk assessment}

When developing an experimental model that will be appropriate for hazard characterisation of allergenicity of novel proteins there are a number of important considerations. The first is that of route of exposure. In the experimental approach described in the present paper test proteins have been administered by intraperitoneal injection, such that the opportunities for the generation of vigorous immune responses are optimised. It may appear that in the context of food allergy oral administration is the most appropriate route of exposure, given that it is the most likely route of sensitisation for man.

Although dietary intake is certainly the most important, and most common, route of exposure for the acquisition of sensitisation to food proteins, there is reason to believe that exposure by other routes to food proteins, or to proteins immunologically cross-reactive with food proteins, may be relevant in some instances. It is possible, for instance, that dermal exposure to certain food proteins may impact on 


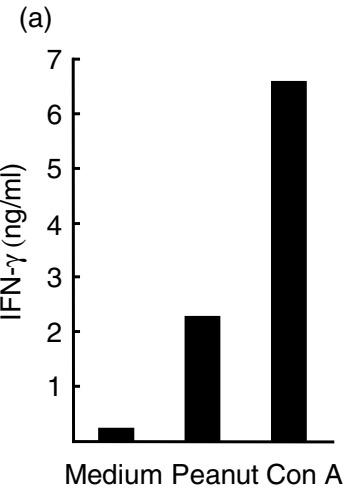

(d)

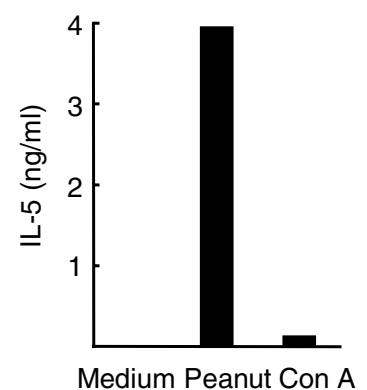

(b)

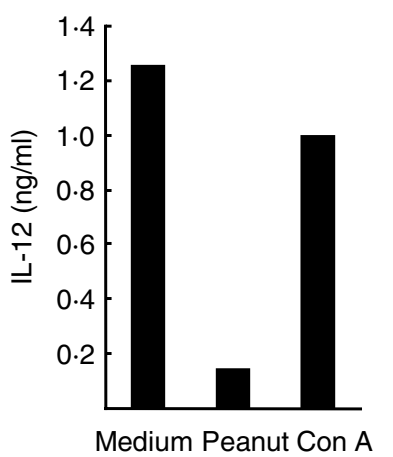

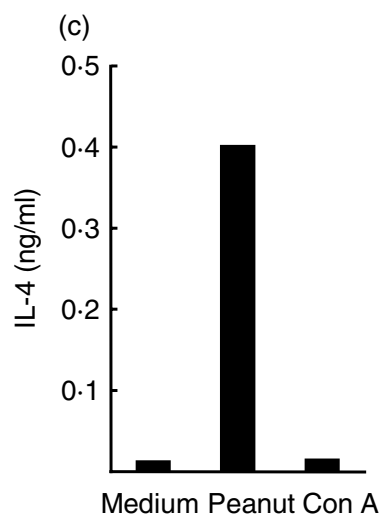

(f)

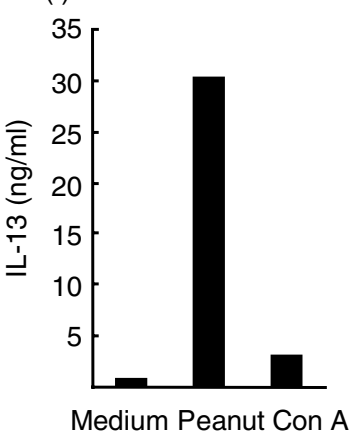

Medium Peanut Con A

(g)

(e)

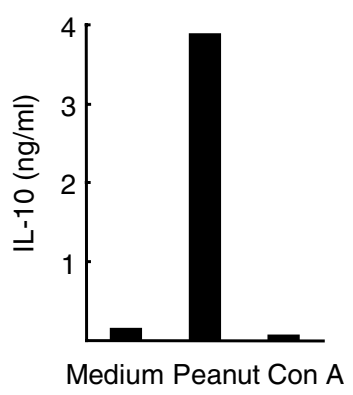

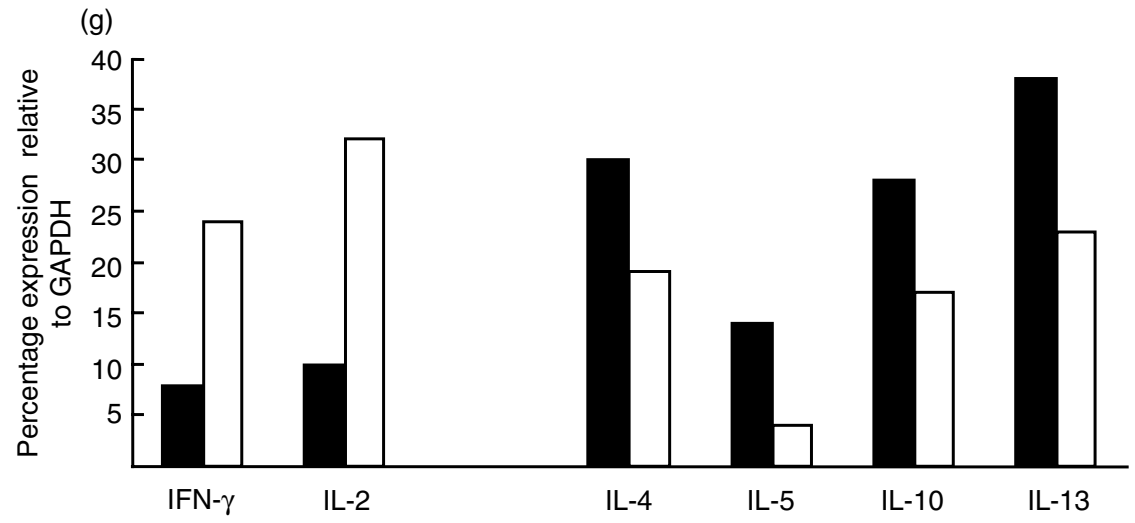

Fig. 2. Cytokine secretion profile induced by exposure to peanut allergen. BALB/c strain mice $(n 10)$ received $30 \mu$ l peanut (Arachis hypogea) agglutinin $(0.2 \%, \mathrm{w} / \mathrm{v})$ in PBS by intradermal injection in the dorsum of both ears on days 0 and 7 . At $14 \mathrm{~d}$ after the initiation of exposure, draining auricular lymph nodes were excised and a single cell suspension of lymph node cells (LNC) prepared by mechanical disaggregation. LNC were cultured at $10^{7}$ cells $/ \mathrm{ml}$ in the presence of the T-cell mitogen concanavalin A (con A; $2 \mu \mathrm{g} / \mathrm{ml}$ ) or purified peanut agglutinin $(200 \mu \mathrm{g} / \mathrm{ml}$ ) or in medium alone for $120 \mathrm{~h}$. Supernatant fractions were harvested and the concentrations of interferon- $\gamma$ (IFN- $\gamma ; \mathrm{a})$, IL-12 (b), -4 (c), -5 (d), -10 (e) and -13 (f) measured by cytokine-specific ELISA. Further aliquots of cells were cultured for $24 \mathrm{~h}$ with con $\mathrm{A}(\square)$ or peanut agglutinin (घ) and RNA was prepared and analysed for cytokine mRNA expression by ribonuclease protection assay (g). Data are expressed as the percentage cytokine mRNA levels relative to the housekeeping gene glyceraldehyde-3-phosphate dehydrogenase (GAPDH). Results from a representative experiment are shown (for detailed experimental protocols, see Betts et al. 2004).

sensitisation. In a longitudinal study investigating factors associated with the development of peanut allergy in childhood, for example, it has been concluded that an important risk factor is cutaneous exposure to peanut oils (Lack et al. 2003). In relation to cross-reactivity, the oral allergy syndrome provides one example (Sloane \& Sheffer, 2001). This syndrome is characterised by IgE-mediated allergic reactions in the oro-pharyngeal mucosa provoked by foods (frequently fruits and vegetables) that contain proteins that are immunologically cross-reactive with pollen proteins to which symptomatic subjects are sensitised (presumably as a result of previous inhalation exposure).

Furthermore, in rodents oral (directly to the stomach) exposure to proteins can be variable or insensitive in relation to the induction of IgE antibody responses (Knippels et al. 1998; Dearman et al. 2001). Thus, although in many experiments daily oral exposure of Brown Norway strain rats to $1 \mathrm{mg}$ ovalbumin/ml results in $80 \%$ IgE-responder 
animals, in a minority of experiments the identical dosing schedule fails to induce specific IgE antibody in any recipient (Knippels et al. 1998). Additionally, in comparative experiments performed with $\mathrm{BALB} / \mathrm{c}$ strain mice it has been observed that only weak and variable $\operatorname{IgE}$ antibody responses are elicited by ovalbumin (a relatively stable allergen) when given orally, whereas the same protein when administered by the intraperitoneal route stimulates vigorous IgE antibody responses (Dearman et al. 2001).

The approach has been to conduct these experiments in the absence of adjuvant, allowing assessment of the inherent potential of a given protein to induce allergic sensitisation (IgE antibody responses). Other investigators have chosen to incorporate adjuvants, such as carrageenan or cholera toxin that are reportedly selective for IgE antibody responses, into immunisation protocols (Atkinson \& Miller, 1994; Atkinson et al. 1996; Li et al. 1999, 2000). While co-administration of adjuvant will undoubtedly increase the sensitivity of detection of IgE antibody responses to proteins, there is some concern that this increase in sensitivity may be achieved at the cost of some loss in selectivity. There is limited evidence to suggest that adjuvant may override the inherent differences between proteins in relation to their ability to induce $\operatorname{IgE}$ antibody, conferring on non-allergens the appearance of sensitising potential (Dearman et al. 1999).

Another issue is that of inter-individual susceptibility to the development of sensitisation. In common with other forms of atopic disease, the pathophysiology of food allergy is complex and inter-individual differences in susceptibility will be governed by a combination of environmental factors, genetic predisposition and exposure conditions, including the age at which first exposure occurs (Kimber \& Dearman, 2002). Given this complexity, it is generally considered that it will not prove possible to define a method using experimental animals that will accurately predict the likely prevalence, persistence and severity of food allergy among human populations exposed to a novel allergen in the diet. Whilst this assessment is undoubtedly correct, the purpose of the approach described in the present paper, and indeed the first step of any safety assessment process, is to identify intrinsic hazard, or lack of it. In this case the intrinsic hazard is identified as a function of the ability of the protein to induce $\operatorname{IgE}$ antibody production and the next steps in the risk assessment process will be to characterise the nature of the hazard and to define potential risks to human subjects based on likely exposure patterns.

\section{Concluding comments}

There is considerable interest in the development of methods for the identification and characterisation of the features that confer on proteins the ability to cause allergic sensitisation, and also in the application of such knowledge to approaches designed to identify potential allergenic hazard. Progress in addressing these issues will undoubtedly facilitate the development and refinement of strategies for evaluating the sensitising potential and potency of novel proteins in the context of food safety assessments.
The conclusion drawn from the evidence to date is that proteins vary in relation to their inherent potential to induce allergic sensitisation. The current view is that some key characteristics of protein allergens favour the selective development of type 2 immune responses and $\operatorname{IgE}$ antibody production. The data presented here suggest that the measurement of antibody (IgE) responses in BALB/c mice appears to identify allergens accurately and to distinguish them from those proteins that apparently lack allergenicity. Further investigations with a wider range of proteins are required, but experience to date suggests that this approach could play an important role in the identification and characterisation of the allergenic potential of novel proteins.

\section{References}

Aalberse RC (2000) Structural biology of allergens. Journal of Allergy and Clinical Immunology 106, 228-238.

Atherton KT, Dearman RJ \& Kimber I (2002) Protein allergenicity in mice: a potential approach for hazard identification. Annals of the New York Academy of Sciences 964, 163-172.

Atkinson HAC, Johnson IT, Gee JM, Grigoriadou F \& Miller K (1996) Brown Norway model of food allergy: effect of plant components on the development of oral sensitization. Food and Chemical Toxicology 34, 27-32.

Atkinson HAC \& Miller K (1994) Assessment of the Brown Norway rat as a suitable model for the investigation of food allergy. Toxicology 91, 281-288.

Astwood JD, Leach JN \& Fuchs RL (1996) Stability of food allergens to digestion in vitro. Nature Biotechnology 14, 12691273.

Bae SJ, Tanaka Y, Hakugawa J \& Katayama I (1999) Interleukin-5 involvement in ovalbumin-induced eosinophil infiltration in mouse food allergy model. Journal of Dermatological Science 21, 1-7.

Betts CJ, Flanagan BF, Caddick HT, Dearman RJ \& Kimber I (2004) Intradermal exposure of BALB/c strain mice to peanut protein elicits a type 2 cytokine response. Food and Chemical Toxicology 42, 1589-1599.

Bock SA, Stoneham MD \& Sampson HA (2001) Fatalities due to anaphylactic reactions to foods. Journal of Allergy and Clinical Immunology 107, 191-193.

Bredehorst R \& David K (2001) What establishes a protein as an allergen? Journal of Chromatography Biomedical Science Applications 756, 33-40.

Bufe A (1998) The biological function of allergens: relevance for induction of allergic disease. International Archives of Allergy and Immunology 117, 215-219.

Burks AW, Cockrell G, Connaughton C, Guin J, Allen W \& Helm RM (1994) Identification of peanut agglutinin and soybean trypsin inhibitor as minor legume allergens. International Archives of Allergy and Immunology 105, 143-149.

Bush RR \& Hefle SL (1996) Food allergens. Critical Reviews in Food Science and Nutrition 36, S119-S163.

Dearman RJ, Basketter DA \& Kimber I (1999) Anti-protein antibody isotype distribution: influence of adjuvant. Immunology Letters 69, 102Abstr.

Dearman RJ, Caddick H, Stone S, Basketter DA \& Kimber I (2001) Characterization of antibody responses induced in rodents by exposure to food proteins: influence of route of exposure. Toxicology 167, 217-231.

Dearman RJ \& Kimber I (2001) Determination of protein allergenicity: studies in mice. Toxicology Letters 120, 181-186. 
Dearman RJ, Skinner RA, Herouet C, Labay K, Debruyne E \& Kimber I (2003a) Induction of IgE antibody responses by protein allergens: inter-laboratory comparisons. Food and Chemical Toxicology 41, 1509-1516.

Dearman RJ, Stone S, Caddick HT, Basketter DA \& Kimber I (2003b) Evaluation of protein allergenic potential in mice: dose-response analyses. Clinical and Experimental Allergy 33, $1586-1594$.

Ermel RW, Kock M, Griffey SM, Reinhart GA \& Frick OL (1997) The atopic dog: a model for food allergy. Laboratory Animal Science 47, 40-49.

Finkelman FD, Katona IM, Mosmann TR \& Coffman (1988a) IFN-gamma regulates the isotypes of Ig secreted during in vivo humoral responses. Journal of Immunology 140, 10221027.

Finkelman FD, Katona IM, Urban JF Jr, Holmes J, Ohara J, Tunge AS, Sample JV \& Paul WE (1988b) IL-4 is required to generate and sustain in vivo IgE responses. Journal of Iтmиnology 141, 2335-2341.

Fogg MI \& Spergel JM (2003) Management of food allergies. Expert Opinion in Pharmacotherapeutics 4, 1025-1037.

Food and Agriculture Organization/World Health Organization (2001) Report of a Joint FAO/WHO Expert Consultation on Allergenicity of Foods Derived from Biotechnology. Rome: FAO/WHO.

$\mathrm{Fu}$ TJ, Abbott U \& Hatzos C (2002) Digestibility of food allergens and non-allergenic proteins in simulated gastric and intestinal fluids - a comparative study. Journal of Agriculture and Food Chemistry 50, 7154-7160.

Hefle SL, Nordlee JA \& Taylor SL (1996) Allergenic foods. Critical Reviews in Food Science and Nutrition 36, S69-S89.

Helm RM (2003) Food biotechnology: is this good or bad? Implications to allergic diseases. Annals of Allergy Asthma and Immunology 90, 90-98.

Helm RM, Furuta GT, Stanley JS, Ye J, Cockrell G, Connaughton C, Simpson P, Bannon GA \& Burks AW (2002) A neonatal swine model for peanut allergy. Journal of Allergy and Clinical Immunology 109, 136-142.

Hollingworth RM, Bjeldanes LF, Bolger M, Kimber I, Meade BJ, Taylor SL \& Wallace KB (2003) Toxicological Sciences 71, 2-8.

Hourihane JOB (1998) Prevalence and severity of food allergy need for control. Allergy 53, 84 .

Huby RDJ, Dearman RJ \& Kimber I (2000) Why are some proteins allergens? Toxicological Sciences 55, 84-88.

Jeannet-Peter N, Piletta-Zanin PA \& Hauser C (1999) Facial dermatitis, contact urticaria, rhinoconjunctivitis, and asthma induced by potato. American Journal of Contact Dermatitis 10, $40-42$.

Kanny G, De Hauteclocque C \& Moneret-Vautrin DA (1996) Sesame seed and sesame seed oil contain masked allergens of growing importance. Allergy 51, 952.

Kimber I \& Dearman RJ (1997) Cell and molecular biology of chemical allergy. Clinical Reviews in Allergy and Immunology 15, 145-168.

Kimber I \& Dearman RJ (2002) Factors affecting the development of food allergy. Proceedings of the Nutrition Society 61, 435-439.

Knippels LM \& Penninks AH (2003) Assessment of the allergic potential of food protein extracts and proteins on oral application using the Brown Norway rat model. Environmental Health Perspectives 111, 233-238.

Knippels LMJ, Penninks AH, Spanhaak S \& Houben GF (1998) Oral sensitization to food proteins: a Brown Norway rat model. Clinical and Experimental Allergy 28, 368-375.

Knippels LMJ, van der Kleij HPM, Koppelman SJ, Houben GF, Penninks AH \& Felius AA (2000) Comparison of antibody responses to hen's egg and cow's milk proteins in orally sensitized rats and food-allergic patients. Allergy 55, 251-258.

Lack G, Chapman M, Kalsheker N, King V, Robinson C \& Venables K (2002) Report on the potential allergenicity of genetically modified organisms and their products. Clinical and Experimental Allergy 32, 1131-1143.

Lack G, Fox D, Northstone K, Golding J \& Avon Longitudinal Study of Parents and Children Study Team (2003) Factors associated with the development of peanut allergy in childhood. New England Journal of Medicine 348, 977-985.

Li X-M, Schofield BH, Huang C-K, Kleiner GI \& Sampson HA (1999) A murine model of IgE-mediated cows milk hypersensitivity. Journal of Allergy and Clinical Immunology 103, 206-214.

Li X-M, Serebrisky D, Lee S-Y, Huang C-K, Bardina L Schofield BH, Stanley JH, Burks AW, Bannon GA \& Sampson HA (2000) A murine model of peanut anaphylaxis: T- and B-cell responses to a major peanut allergen mimic human responses. Journal of Allergy and Clinical Immunology 106, $150-158$.

Lucas JS, Grimshaw KE, Collins K, Warner JO \& Hourihane JO (2004) Kiwi fruit is a significant allergen and is associated with differing patterns of reactivity in children and adults. Clinical and Experimental Allergy 34, 1115-1121.

Metcalfe DD, Astwood JD, Townsend R, Sampson HA, Taylor SL \& Fuchs RL (1996) Assessment of the allergenic potential of foods derived from genetically engineered crop plants. Critical Reviews in Food Science and Nutrition 36, S165S186.

Morafo V, Srivastava K, Huang C-K, Kleiner G, Lee S-Y, Sampson HA \& Li X-M (2003) Genetic susceptibility to food allergy is linked to differential Th1-Th2 responses in C3H-HeJ and $\mathrm{BALB} / \mathrm{c}$ mice. Journal of Allergy and Clinical Immunology 111, 1122-1128.

Mosmann TR, Cherwinski H, Bond MW, Giedlin MA \& Coffman RL (1986) Two types of murine helper T cell clone. I. Definition according to profiles of lymphokine activities and secreted proteins. Journal of Immunology 136, 2348-2357.

Mosmann TR \& Coffman RL (1989) Heterogeneity of cytokine secretion patterns and functions of helper T cells. Advances in Immunology 46, 111-145.

Mosmann TR, Li L \& Sad S (1997) Functions of CD8 T-cell subsets secreting different cytokine patterns. Seminars in Immunology 9, 87-92.

Mosmann TR \& Sad S (1996) The expanding universe of T-cell subsets: Th1, Th2 and more. Immunology Today 17, 138-146.

Pumphrey RS (2000) Lessons for management of anaphylaxis from a study of fatal reactions. Clinical and Experimental Allergy 30, 1144-1150.

Sampson HA (1988) IgE-mediated food intolerance. Journal of Allergy and Clinical Immunology 81, 495-504.

Sampson HA (2004) Update on food allergy. Journal of Allergy and Clinical Immunology 113, 805-819.

Selgrade MK, Kimber I, Goldman L \& Germolec DR (2003) Assessment of allergenic potential of genetically modified foods: an agenda for future research. Environmental Health Perspectives 111, 1140-1141.

Sloane D \& Sheffer A (2001) Oral allergy syndrome. Allergy and Asthma Proceedings 22, 321-325.

Spergel JM, Beausoleil JL \& Pawlowski NA (2000) Resolution of childhood peanut allergy. Annals of Allergy Asthma and Immunology 85, 473-476.

Taylor SL \& Hefle SL (2001) Will genetically modified foods be allergenic? Journal of Allergy and Clinical Immunology 107, 765-771. 
Teuber SS, Del Val G, Morigasaki S, Jung HR, Eisele PH, Frick OL \& Buchanan BB (2002) The atopic dog as a model of peanut and tree nut food allergy. Journal of Allergy and Clinical Immunology 110, 921-927.

Thomas K, Aalbers M, Bannon GA, Bartels M, Dearman RJ, Esdaile DJ et al. (2004) A multi-laboratory evaluation of a common in vitro pepsin digestion assay protocol used in assessing the safety of novel proteins. Regulatory Toxicology and Pharmacology 39, 87-98.

Turcanu V, Maleki SJ \& Lack G (2003) Characterization of lymphocyte responses to peanuts in normal children, peanut-allergic children, and allergic children who acquired tolerance to peanuts. Journal of Clinical Investigation 111, 1065-1072.

van Wijk F, Hartgring S, Koppelman SJ, Pieters R \& Knippels LM (2004) Mixed antibody and T cell responses to peanut and the peanut allergens Ara h 1, Ara h 2, Ara h 3 and Ara h 6 in an oral sensitization model. Clinical and Experimental Allergy 34, 1422-1428.

Young E, Stoneham MD, Petruckevitch A, Barton J \& Rona R (1994) A population study of food intolerance. Lancet 343, $1127-1130$. 